Article

\title{
Rural Housing Vacancy in Metropolitan Suburbs and Its Influencing Factors: A Case Study of Nanjing, China
}

\author{
Liyuan Zhao and Xingping Wang *
}

check for updates

Citation: Zhao, L.; Wang, X. Rural Housing Vacancy in Metropolitan Suburbs and Its Influencing Factors: A Case Study of Nanjing, China. Sustainability 2021, 13, 3783. https:// doi.org/10.3390/su13073783

Academic Editor: Piotr Prus

Received: 5 February 2021

Accepted: 25 March 2021

Published: 29 March 2021

Publisher's Note: MDPI stays neutral with regard to jurisdictional claims in published maps and institutional affiliations.

Copyright: (c) 2021 by the authors. Licensee MDPI, Basel, Switzerland. This article is an open access article distributed under the terms and conditions of the Creative Commons Attribution (CC BY) license (https:// creativecommons.org/licenses/by/ $4.0 /)$.
School of Architecture, Southeast University, Nanjing 210096, China; 230139573@seu.edu.cn

* Correspondence: 101010501@seu.edu.cn

\begin{abstract}
With the rapid development of industrialization and urbanization, rural housing vacancy (RHV) has become an increasingly universal phenomenon in China, causing many economic and social problems. Despite many studies on RHV, relatively little attention has been paid to distinguishing the types of vacant rural houses as well as RHV in metropolitan suburbs. Drawing upon survey data from 23 sampled villages of the Nanjing metropolitan area in China, this paper differentiates RHV into permanent vacancy and temporary vacancy and analyzes the influences of location, government interventions, and the villages' characteristics on the two types of RHV. The empirical results show that villages located in inner suburbs and with medium travel time to city centers have higher permanent RHV rates, while those located further away from city centers usually have higher temporary RHV rates. The local government's restrictive plans and housing construction restrictions do not increase the permanent RHV rate nor temporary RHV rate, whereas supportive plans and financial investment reduce the permanent RHV rate and increase the temporary RHV rate. Permanent RHV rates are relatively lower in villages that are less reliant on agricultural development. Those villages usually have higher sublet rates of farmland, a lower proportion of agriculture laborers, and better development of manufacturing or tourism. However, temporary RHV rates do not differ significantly between agricultural villages and non-agricultural villages. The paper finds an unusual "middle bump" phenomenon of permanent RHV rate and explains it with the law of commuting circles. Some policy implications are put forward to promote the transformation and sustainable development of rural areas in China's metropolitan suburbs.
\end{abstract}

Keywords: rural housing vacancy; permanent vacancy; temporary vacancy; metropolitan suburbs; rural transformation; Nanjing

\section{Introduction}

In the context of rapid industrialization and urbanization, rural housing vacancy (RHV) characterized by rural depopulation has become an increasingly universal phenomenon across the world. For instance, the United States experienced a remarkable process of rural depopulation in the 1960s, with its rural communities suffering economic stagnation, high rates of poverty, erosion of public services, and limited well-being [1]. Over the last decades, Japan has also undergone a similar process [2]. Even in European countries such as Spain, Italy, and Germany, as rural residents are continuing to move to urban areas with more employment opportunities and higher incomes, many villages are faced with problems of depopulation, increasing aging, slow industrial development, and stagnation of public facilities [3-5]. It is estimated that the rural population in Europe may decrease by another 7.9 million by 2050 [6].

In China, the problem of rural demographic decline might be even more serious. Since the reform and opening up in 1978, China's urbanization has developed rapidly. Its urbanization rate exceeded 50\% in 2011 and reached $60.6 \%$ in 2019. Since the mid-1990s, China's rural population has continued to decrease, whereas the construction land for rural housing has kept increasing. This means that a large number of rural houses were left 
unused. According to the statistics published by the government in 2014, the completely vacant rural construction land area was about 30 million $\mathrm{mu}(1 \mathrm{mu}=1 / 15$ hectares), and the inefficiently rural construction land area was about 90 million mu nationwide [7] (p. 22). It is estimated that the short-term land consolidation potential in China is 114 million mu and the long-term potential is 149 million mu [8] (p. 3).

As rural residents moved out from their villages and abandoned their rural houses, the problem of "hollow villages" emerged in many of China's rural areas [8] (p. 1). This problem has directly caused waste of land resources, agricultural decline, and food safety hazards $[9,10]$. In addition, it has led to many associated problems such as change of rural population structure, inefficient supply of public service facilities, and deterioration of rural residents' living environment [11]. Therefore, it is of great significance to better understand China's RHV which is key to promote the revitalization and sustainable development of China's rural areas [12].

Existing studies on China's RHV can be generally classified into three categories. The first category is descriptive analyses of China's RHV phenomenon at different geographical scales. At the micro-scale, for instance, it is found that vacant houses in rural areas are characterized by "peripheral expansion and center vacancy" and the average RHV rate is about 15\% [13]. At the macro scale, some studies have observed a non-coupling relationship between the rural population decline and increased rural housing areas [14,15]. In addition, empirical studies have put forward many methodologies in describing the phenomenon of RHV [16,17].

The second category is policy analyses of China's RHV. In response to the systemic rural decline, the government proposed the "New Countryside Construction Action" in 2005 [18] and used the "Linking the Increase of Urban Construction Land with the Decrease of Rural Construction Land" policy to promote the building of concentrated "New Rural Communities" [19]. However, the reconstruction of rural space is more than a transformation of land functions, it is a systematic project. It is necessary to not only promote the land system reform but also to fully respect the farmers' needs [20]. Therefore, recent studies have introduced social network analysis and focused on residents' willingness to participate when analyzing villages' mergers and rural land consolidation [21,22]. In addition, bottom-up initiatives of rural residents and the coordination of related policies and plans have been increasingly emphasized in recent studies [23].

The third category is mechanism analyses of China's RHV. At the micro-level, China's RHV has been mainly understood from the perspective of family migration decisionmaking. For example, some studies have analyzed the influences of personal characteristics, family income, housing areas, and housing construction time on a family's migration activity [24,25]. However, due to the impact of COVID-19, the working opportunities and income of certain rural migrants in China have been adversely affected [26,27], and the urban-rural relationship is being re-examined [28]. A recent study in Wuhan shows that people's willingness to live in the countryside has increased [29], which may increase the use of rural houses. At the meso-level, some studies have explained the differences in RHV rates from the perspective of villages' regional spatial conditions. For example, it has been found that a village's location, economic development level, and natural geographic conditions are all important factors affecting the RHV rate [30-34]. At the macro level, the urban-rural relationship has been found as a major contributor to China's RHV. For example, some scholars argue that RHV is the result of the combined effect of the pull of the city and the push of the countryside [35]. Urbanization, industrialization, social and cultural traditions, China's special land system, and defects of rural housing construction management system are all macro factors accounting for China's RHV [36].

Within this line of literature, however, there still exist some research gaps that need to be further explored. First, previous studies have mainly focused on rural areas with massive population outflows, which are dominated by an agricultural economy, while relatively little attention has been paid to China's metropolitan suburbs [34]. However, addressing the RHV issue could be of great significance for the long-term sustainable 
development of China's metropolitan suburbs where rural villages have been greatly affected by the expansion of city construction land [37,38]. In fact, our fieldwork shows that the suburbs of Chinese metropolitan areas such as Nanjing, Suzhou, and Hangzhou have been faced with serious RHV issues. Second, that RHV could have different types has been mainly overlooked in existing studies. In fact, most studies have only taken the seasonal vacancy of rural houses as the key problem, which may cause inefficiency of certain policies [39]. Given the two research gaps, this paper aims to answer the following two questions: (1) are there different RHV types in China's metropolitan suburbs? and (2) if so, what are the factors that account for the differentiation of RHV?

The remainder of this paper is organized as follows. Section 2 reviews the literature and puts forward the theoretical framework discussing the differentiation of RHV rates and its influencing factors; Section 3 describes the research area, data, and methodology. Section 4 discusses the empirical results and policy implications. Section 5 concludes.

\section{Literature Review and Theoretical Framework}

\subsection{Literature Review}

RHV in metropolitan suburbs has essentially reflected differentiated spatial development at the regional scale. Therefore, we draw upon studies that have analyzed the influencing factors of regional spatial development differentiation to summarize the main factors affecting the RHV. These factors are grouped into three categories including location, government interventions, and village characteristics.

Location factors and the development of rural space. The classic location theory proposes that the decision-making of human economic activities is affected by location, which in turn affects regional spatial structure [40]. For example, a study on rural space of the Ruhr metropolitan area in Germany shows that location affects the development of suburban agriculture, and farms with location advantages are more inclined to adopt diversified development strategies [41]. A study on Bangalore, India finds that suburban farmers' rental and commuting activities between their urban workplaces and rural residences are affected by the mode and distance of transportation [42]. In China, many studies on RHV show that there is a correlation between location factors and the difference in villages' RHV rate. Some empirical studies have shown that villages further away from the city have a higher RHV rate because these villages have a higher proportion of villagers working in the city $[8,30,32]$. However, other studies have reached the opposite conclusion. They find that in some metropolitan suburbs, villages that are closer to the city center and have more convenient transportation have higher RHV rates because rural people are more likely to leave the country and enter the city [33,34].

Government interventions and the development of rural space. In China, the direct interventions of local government have a great impact on spatial differentiation. Local governments could affect the utilization and development of urban and rural spaces through a series of interventions such as special institutions, urban planning, and financial investments. For example, the number and distribution of public service facilities provided by local governments could affect the spatial distribution of employment [43], while urban and rural planning and investment activities of local governments could affect the economic and social development trajectory of villages [34,44-46]. Besides, government interventions such as land consolidation policies, new rural construction policies, and industrial promotion policies have restructured rural space [47].

Village characteristics and the development of rural space. The "push-pull" theory points out that population migration decision-making is affected by the combined effect of urban pull and rural push, that is, whether people will move out of the countryside is also related to the economic and social development condition of the village itself $[24,48,49]$. Previous studies have found that population migration is related to local economic growth, employment opportunities, income levels, social welfare, and public services [50]. For rural population migration, studies have found that transport conditions, economic development stages, natural resource base, and community terrain conditions are all important factors 
affecting the migration decision of rural residents [33,35]. In general, a higher economic and industrial development level, better resource base of the village, and higher dependence of villagers on farmland leads to a lower RHV rate [51].

\subsection{Theoretical Framework}

\subsubsection{Two Types of RHV}

Though there are many studies on China's RHV, relatively little attention has been paid to distinguishing the types of vacant houses [39]. However, based on our field surveys in the suburbs of some metropolitan areas, there are different types and causes of vacant rural houses. Some seriously damaged and completely abandoned rural houses have indeed caused the decline of rural spaces and the deterioration of the living environment in villages. Some seasonal or cyclically vacant rural houses do not lead to rural recession. In fact, they are the nodes where urban elements and rural society are connected, and they might even be conducive to the long-term development of rural areas in metropolitan suburbs. Therefore, distinguishing the different types of RHV could shed more light on the transformation and sustainable development of China's rural areas.

In general, RHV can be defined as a state of space insufficient utilization because a family's life cycle end or all family members moved out from their rural houses while at the same time new users are unable or unwilling to move in. Drawing upon previous studies, this study differentiates permanent RHV and temporary RHV by comparing the time that rural houses are being utilized. Permanent RHV refers to a situation where a rural house has not been used for a long time and it will no longer be used as a living space in the future if there are no fundamental changes in China's current dual urban-rural land system. Permanent RHV is indeed a serious problem that needs to be addressed. In contrast, temporary RHV refers to a situation where a rural house is only used for part of a year (e.g., on some important festivals). Though this type of vacant rural house is not used as a family's daily dwelling, it still has the secondary living function. In this sense, temporary RHV might be a problem for the sustainable development of rural areas, but it may also be used as a strategy to solve the problem of rural recession. Furthermore, RHV rates can be defined as the ratio of the number of vacant houses to the total number of houses in a village. Given the two types of RHV, the RHV rates also include the permanent RHV rate and temporary RHV rate.

\subsubsection{Factors Influencing RHV}

Through the literature review of the influencing factors of RHV from the regional perspective, it can be considered that the difference of the two types of RHV rates in metropolitan suburbs is the result of interactions of location [30-34], government interventions [34,44-47,51], and the villages' characteristics [33,35,51]. We put forward three working hypotheses based on the literature. Figure 1 depicts our theoretical framework of factors affecting RHV rates in metropolitan suburbs.

Hypothesis 1. Villages closer to the city centers may have lower RHV rates than villages further away from the city centers. At present, China's rural development is greatly affected by cities [36]. When the village is closer to the city center and travel time to the city is shorter, it means that it can more easily obtain the radiation of urban functions [8,30]. Residents of this kind of village can live in the countryside but work in the city [34], even migrant workers would rent villagers' houses [37,38], therefore, we hypothesize that the two types of RHV rates would be lower.

Hypothesis 2. Villages that received more supportive measures from the government would have lower $R H V$ rates, while villages restricted by the government would have relatively higher $R H V$ rates. The government's supportive measures, such as formulating special plans, investing sufficient funds, and improving infrastructure for the village [34,44,51], mean that this village is more suitable for living and even new industries would develop [45,46]. In this type of village, residents can obtain employment opportunities and good living conditions, and the motivation of villagers to 
leave the village would be reduced. Therefore, the two types of RHV rates may be lower. On the contrary, villages affected by restrictive government measures may have poorer livability and rural residents are more inclined to move out of the village, thus we hypothesize that both types of RHV rates in this village would increase.

Hypothesis 3. Villages tend to have lower RHV rates if they have better economic foundations or their people are more reliant on rural economic elements. If the village has a better development of non-agricultural industries, such as manufacturing and tourism, it might be able to provide more employment opportunities [33,45,51], and its residents will be able to work and live in the village [45,46]. Therefore, the village's $R H V$ rate should be lower. Moreover, if the villagers are more closely connected with the rural economic elements, for example, the family has a larger amount of farmland, then the possibility of this family moving out of the village would be lower [35,51], and the $R H V$ rate of the village should also be lower.

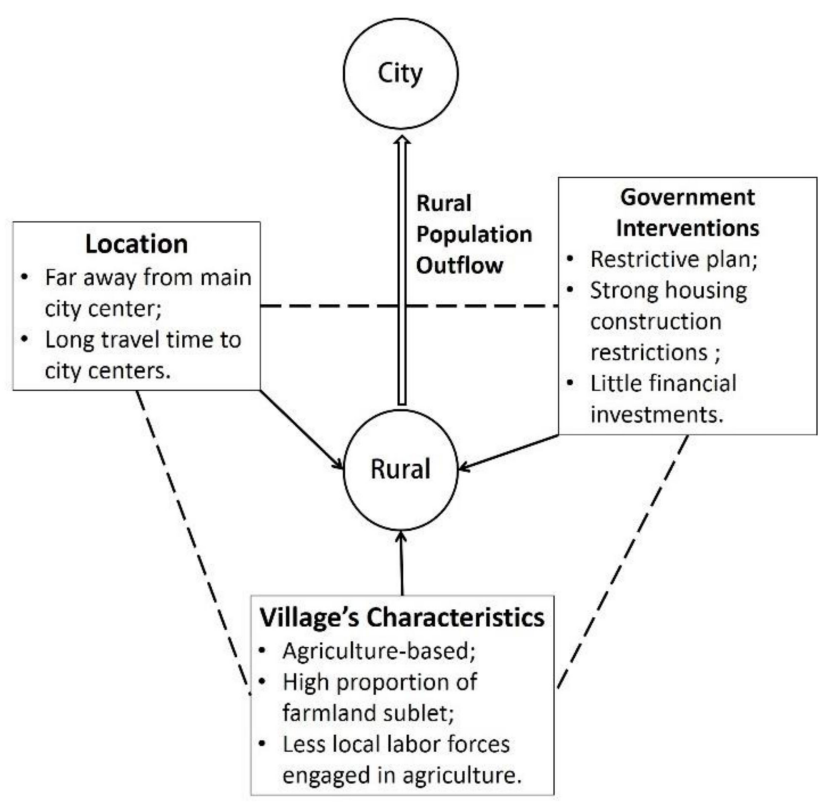

(a)

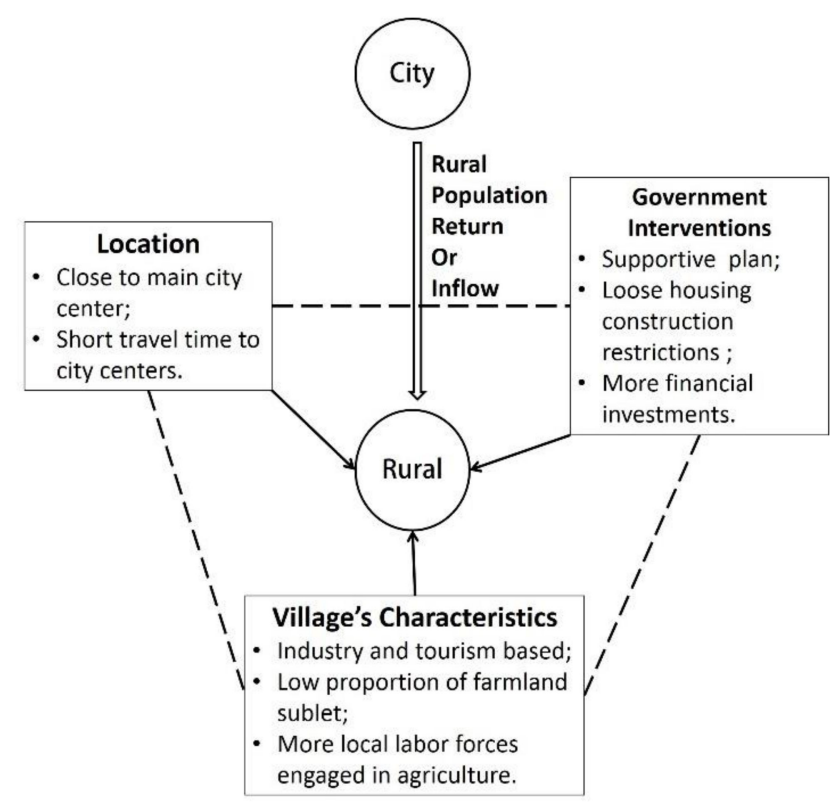

(b)

Figure 1. Theoretical framework of factors influencing rural housing vacancy (RHV) rates in metropolitan suburbs: (a) village with rural population outflow and high RHV rate; (b) village with rural population return/inflow and low RHV rate. (Source: These figures are depicted by the authors).

\section{Research Area, Data, and Methodology}

\subsection{Research Area and Data}

This paper takes villages in Nanjing's metropolitan suburbs as the research area. Nanjing is the capital of Jiangsu Province and an important central city in eastern China. It covers an area of $6587 \mathrm{Km}^{2}$ and has 11 administrative districts. In 2019, Nanjing's GDP was 1171.5 billion yuan, its registered population was 6.81 million, and its permanent population was 8.27 million. Nanjing's urbanization rate reached $82 \%$ in 2019 , which is much higher than the national average level. As is typical for metropolitan areas in China, over the past two decades Nanjing has formed a polycentric and networked spatial structure [52].

Before this study, the authors had completed a study on the development of small towns in the process of metropolitanization [53]. We surveyed about 50 towns in and around the outskirts of Nanjing and gained a systematic understanding of the development of small towns and villages in the metropolitan suburbs. On this basis, we further selected 26 administrative villages from two dimensions of the village's spatial location and village's industrial development to conduct a detailed comprehensive field investigation. Finally, 23 villages were selected as the study samples with the classified sampling method 
(Figure 2). These samples are located in five administrative districts of Nanjing and faced with different situations of RHV, which can reflect the characteristics of different types of RHV in metropolitan suburbs well.
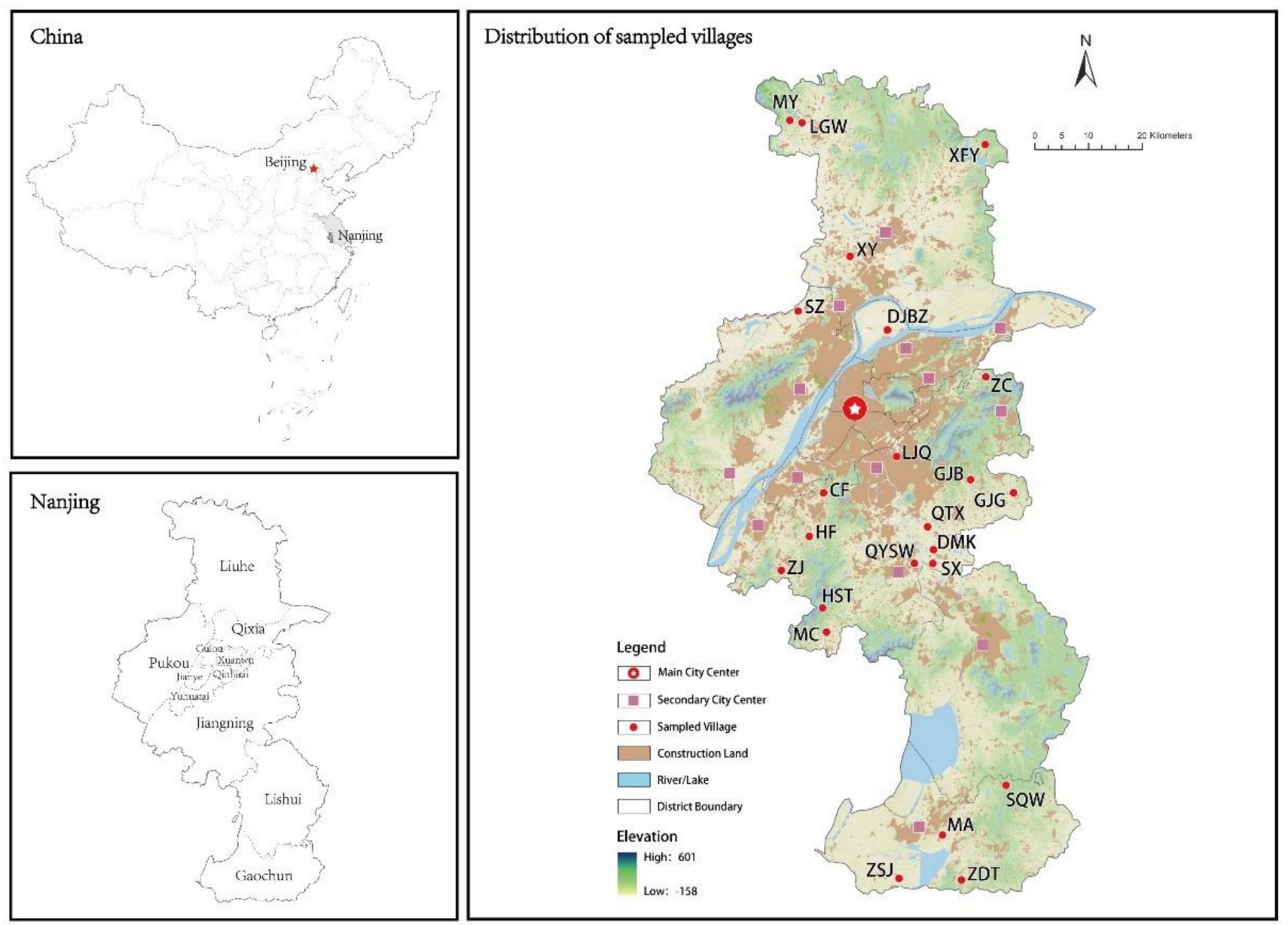

Figure 2. Distribution of 23 sampled villages in Nanjing, China. CF, LJQ, ZC, XY, HF, HST, DJBZ, DMK, SZ, QYSW, SX, QTX, ZJ, GJB, GJG, MA, SQW, MY, LGW, XFY, MC, ZSJ, and ZDT are the abbreviations of the sampled villages: CaoFang, LuJiaQiao, ZhouChong, XuanYe, HouFen, HouShiTang, DongJiangBaZu, DouMenKou, ShenZhuang, QianYangShuWan, ShanXi, QianTangXi, ZhangJia, GeJiaBian, GanJiaGang, MaAo, ShiQiangWei, MeiYing, LiGongWu, XiaoFanYing, MeiCun, ZhangShuJiao, and ZhuDunTou. (Source: This figure is depicted by the authors).

Based on Google satellite maps, we drew maps of the rural houses of 23 sampled villages and then conducted detailed investigations on the use or vacancy status of each house in each sampled village through field surveys from June 2016 to February 2017. Both permanent vacant houses and temporary vacant houses are common in these sampled villages (Figures 3 and 4). In addition, through semi-structured interviews and questionnaire surveys to village managers and villagers, we also collected detailed information. Finally, 26 officials of administrative villages and 23 natural villages' cadres accepted our face-to-face interviews. In addition, we completed a questionnaire survey of 113 households during the field investigations of vacant rural houses in sampled villages, accounting for $4.9 \%$ of the total 2295 registered families. By analyzing the daily activities of rural households, such as residence, employment, commuting, and farmland management, we can better understand the mechanism of RHV. 


\subsection{Methodology}

\subsubsection{Measurement of RHV Rates}

As mentioned above, the RHV rate includes the permanent RHV rate and the temporary RHV rate. While the former refers to the ratio of the number of permanent vacant houses to the total number of houses of a village, the latter refers to the ratio of the number of temporary vacant houses to the total number of houses of a village. The expressions of the two types of RHV rates are as follows.

$$
\begin{aligned}
& P R_{i}=P_{i} / Q_{i} \times 100 \% \\
& T R_{i}=T_{i} / Q_{i} \times 100 \%
\end{aligned}
$$

where $P R_{i}$ represents the permanent RHV rate, $T R_{i}$ represents the temporary RHV rate, $P_{i}$ denotes the number of permanent vacant houses, $T_{i}$ is the number of temporary vacant houses, and $Q_{i}$ represents the total number of houses in a village.

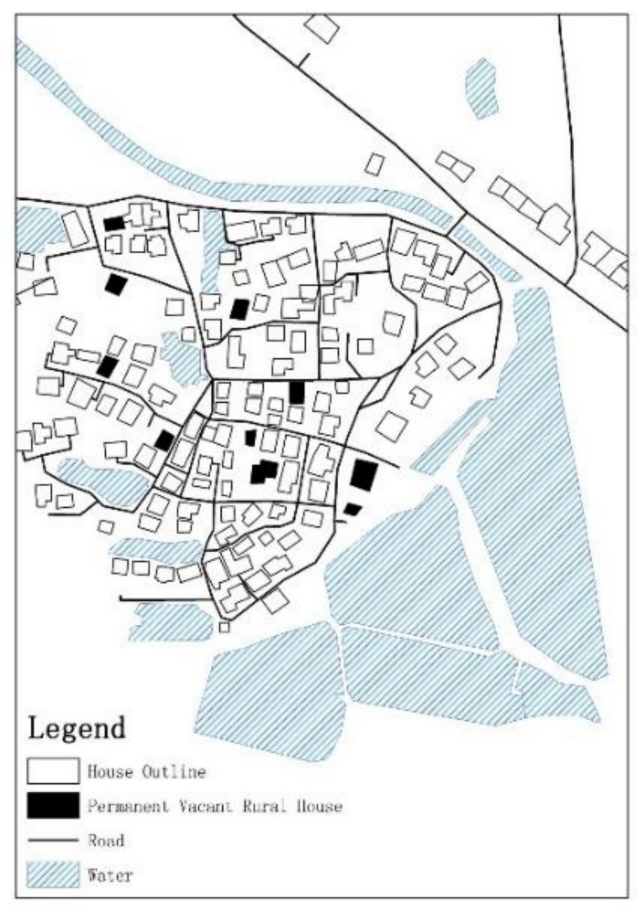

(a)

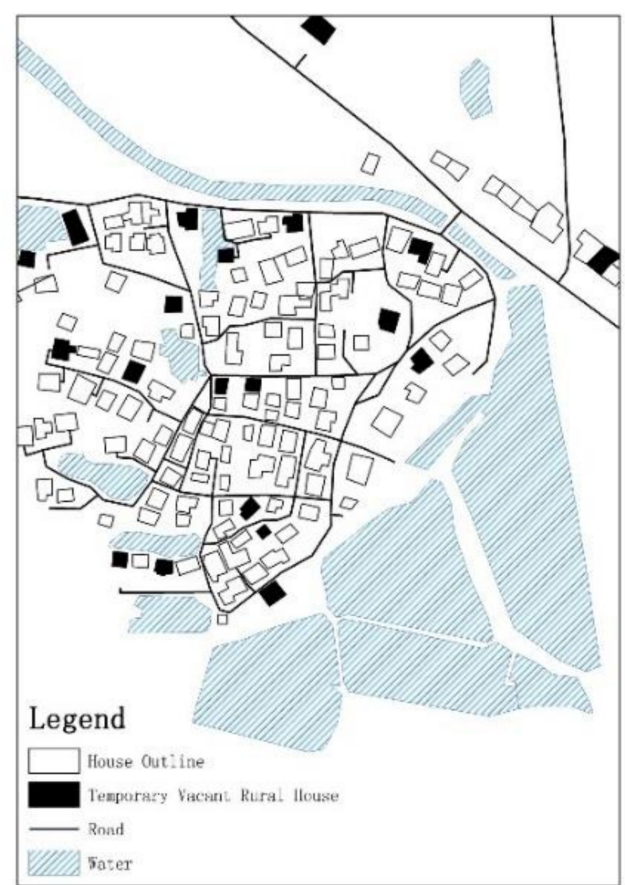

(b)

Figure 3. Distribution of two types of vacant rural houses in a sampled village: (a) permanent vacant rural houses in ZDT; (b) temporary vacant rural houses in ZDT. (Source: These maps are depicted based on the authors' field survey data). 


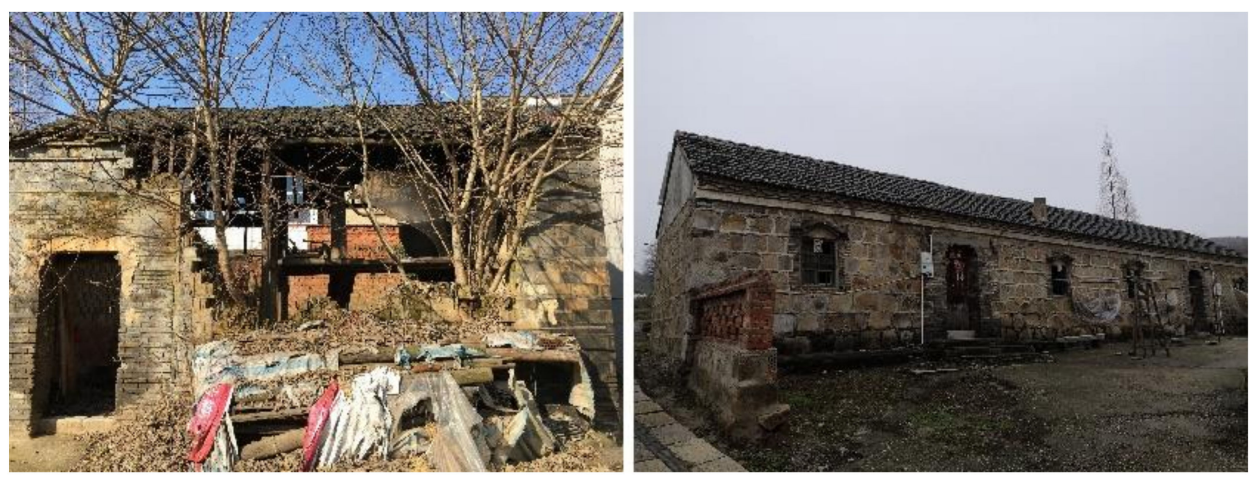

(a)

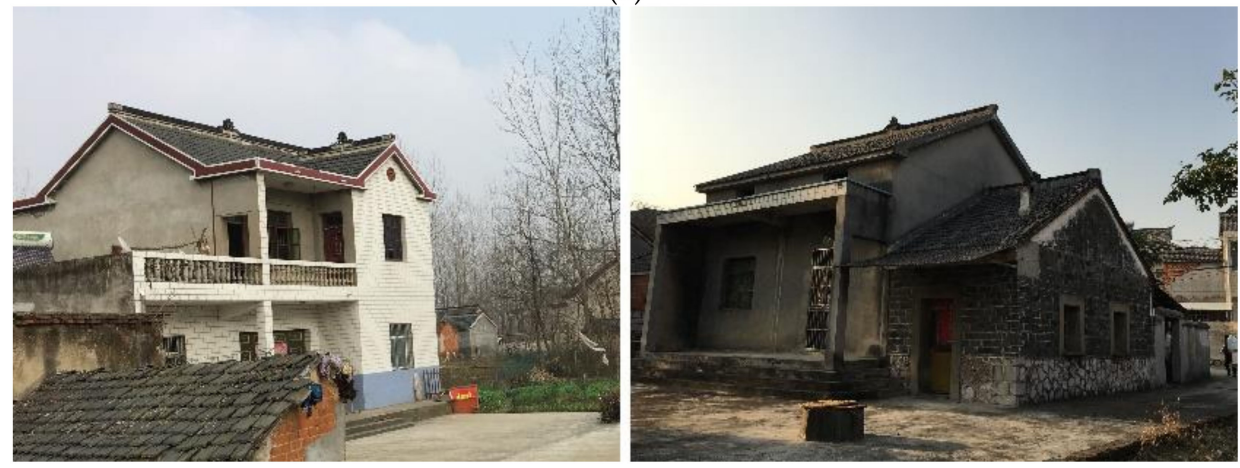

(b)
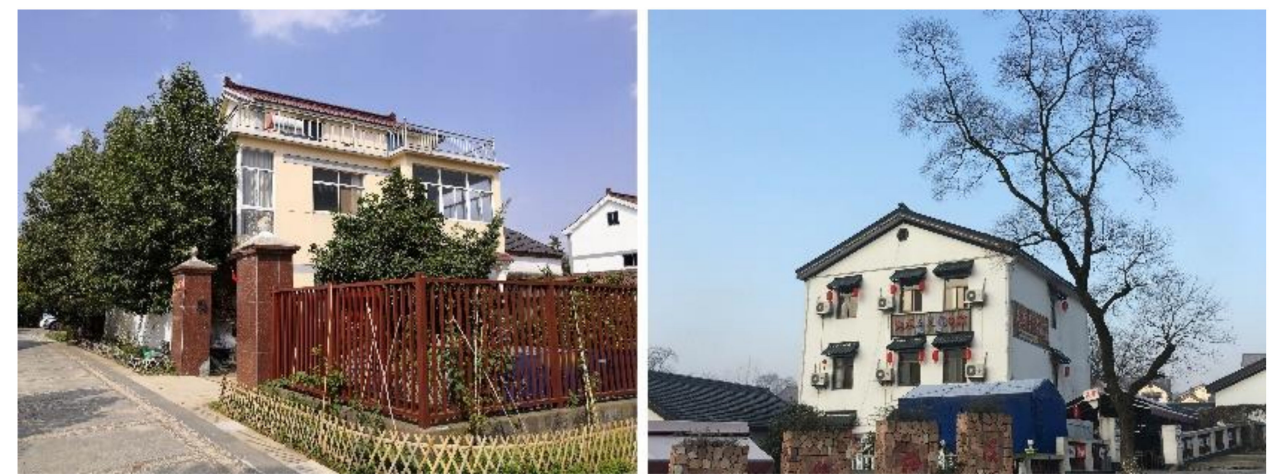

(c)

Figure 4. Different types of rural houses in sampled villages: (a) typical permanent vacant rural houses; (b) typical temporary vacant rural houses; (c) typical daily used rural houses. (Source: These photos were taken by the first author).

\subsubsection{Measurement of Influencing Factors}

Based on a literature review and our fieldwork, we selected ten variables to represent the above-mentioned three factors that could influence the two types of RHV rates in our sampled villages (Table 1). Specifically, the location factor of a village is represented by three variables, which include a spatial circle where the village is located, travel time from the village to the main center of Nanjing, and travel time from the village to the secondary center of Nanjing. Theoretically, the RHV rate of a village would increase from the city center to the periphery $[8,30,32]$. This is because the impact of the city's functional radiation on a village usually decreases as the village's distance to the city center increases [30,32], thereby it is easier for houses to become vacant if they are in a village that is farther away from the city center. In addition, the shorter the travel time from a village to city centers, the more easily its rural residents can access the various economic and service resources, and the less likely it becomes for the village's houses to become vacant [33,34]. 
Table 1. Variables definition and the impact expectations.

\begin{tabular}{|c|c|c|c|c|}
\hline Categories & Variables & Abbreviation & Definition and Description & Impact Expectation \\
\hline \multirow{3}{*}{ Location } & $\begin{array}{l}\text { Spatial circle where the } \\
\text { village is located }\end{array}$ & SCL & $\begin{array}{l}\text { Metropolitan fringe }=1 \\
\text { Inner suburbs }=2, \text { Outer } \\
\text { suburbs }=3\end{array}$ & $\begin{array}{l}\text { The RHV rates would increase as } \\
\text { the village's location changes } \\
\text { from inside to outside of the } \\
\text { metropolitan spatial circle. }\end{array}$ \\
\hline & $\begin{array}{l}\text { Transit time to the main } \\
\text { city center }\end{array}$ & TTMC & Minutes & \multirow{2}{*}{$\begin{array}{l}\text { The RHV rates would increase as } \\
\text { the travel time from the village } \\
\text { to the city centers increases. }\end{array}$} \\
\hline & $\begin{array}{l}\text { Transit time to the } \\
\text { secondary city center }\end{array}$ & TTSC & Minutes & \\
\hline \multirow{4}{*}{$\begin{array}{l}\text { Government } \\
\text { Interventions }\end{array}$} & City master plan & $\mathrm{CMP}$ & $\begin{array}{l}\text { Village is within the urban } \\
\text { development boundary }=1 \text {, } \\
\text { Village is outside the urban } \\
\text { development boundary }=2\end{array}$ & $\begin{array}{l}\text { The livability of villages within } \\
\text { the urban development } \\
\text { boundary is poor, so its RHV } \\
\text { rates may be higher. }\end{array}$ \\
\hline & Village layout plan & VLP & $\begin{array}{c}\text { Plan reserved village }=1, \\
\text { Plan unreserved village }=2\end{array}$ & $\begin{array}{l}\text { Village plan to be reserved can } \\
\text { get more support and has a good } \\
\text { living environment, so the RHV } \\
\text { rates would be lower. }\end{array}$ \\
\hline & $\begin{array}{l}\text { Housing construction } \\
\text { restriction }\end{array}$ & HCR & $\begin{array}{c}\text { No new approval or } \\
\text { renovation }=1, \text { No new } \\
\text { approval but renovation } \\
\text { allowed }=2 \text {, Allow new } \\
\text { approval and renovation }=3\end{array}$ & $\begin{array}{l}\text { The more restrictions on rural } \\
\text { housing construction, the worse } \\
\text { livability of the village, and the } \\
\text { higher the RHV rates. }\end{array}$ \\
\hline & Financial investment & FI & 10,000 yuan & $\begin{array}{l}\text { When the village receives more } \\
\text { financial investment, the } \\
\text { possibility of village } \\
\text { development is greater, and its } \\
\text { RHV rates should decrease. }\end{array}$ \\
\hline \multirow{3}{*}{$\begin{array}{c}\text { Village's } \\
\text { Characteristics }\end{array}$} & Industry development & ID & $\begin{array}{c}\text { Village has manufacture } \\
\text { development }=1, \text { Village has } \\
\text { tourism development }=2, \\
\text { Village only has agricultural } \\
\text { development }=3\end{array}$ & $\begin{array}{c}\text { Village with non-agricultural } \\
\text { development has more job } \\
\text { opportunities and villagers can } \\
\text { work and live nearby, so its RHV } \\
\text { rates would be lower. }\end{array}$ \\
\hline & $\begin{array}{l}\text { Farmland subletting } \\
\text { rate }\end{array}$ & FSR & $\begin{array}{c}100 \%=1,80-100 \%=2 \\
50-80 \%=3,30-50 \%=4 \\
<30 \%=5\end{array}$ & \multirow{2}{*}{$\begin{array}{c}\text { The higher farmland sublet rate } \\
\text { and lower proportion of local } \\
\text { agriculture workers indicate } \\
\text { higher RHV rates. }\end{array}$} \\
\hline & $\begin{array}{l}\text { Proportion of local } \\
\text { workers engaged in } \\
\text { agriculture }\end{array}$ & PLA & $\begin{array}{l}<10 \%=1,10-30 \%=2 \\
30-50 \%=3,>50 \%=4\end{array}$ & \\
\hline
\end{tabular}

The factor of government interventions is reflected by four variables including the city's master plan, village layout plan, housing construction restrictions, and financial investment. In theory, the local government's plans which restrict a village's development would increase the RHV rates, while the plans which support a village's development would reduce the RHV rates [34,43]. The local government's restrictive measures for village housing construction may lead to deterioration of the rural living environment and thereby the increase of RHV rates [47,51]. More financial investments from the local government to a village would improve the livability of the village and therefore reduce its RHV rates [44-46].

The factor of the villages' characteristics is represented by three variables, which include industrial development, farmland subletting rates, and the proportion of agricultural workers to the total workers of a village. Theoretically, in villages where nonagricultural industries are well developed, residents could obtain employment opportunities nearby [33,51], and thus the RHV rates could be at a relatively lower level. If a village's 
farmland sublet rate is higher and the proportion of local laborers engaged in agriculture is lower, its rural residents would be less bound by rural economic activities and more people will migrate to the city $[35,51]$. In this sense, the RHV rates of this village would be higher.

\subsection{Descriptive Analysis of Survey Data}

Table 2 shows the descriptive analysis of our survey data. Obviously, almost all of the sampled villages are faced with the issues of both permanent RHV and temporary RHV and the difference in the two types of RHV rates among villages is remarkable. Specifically, the average permanent RHV rate of sampled villages is about $8.1 \%$, with 8 out of the 23 sampled villages exceeding $10 \%$. The highest permanent RHV rate of the sampled village is over $20 \%$, which is even higher than the average hollowing rate of villages in agricultural areas $[13,30,32]$. The average temporary RHV rate is about $6 \%$, with the highest temporary RHV rate being close to $25 \%$ and the lowest being zero.

Table 2. Description of survey data of sampled villages.

\begin{tabular}{|c|c|c|c|c|c|c|c|c|c|c|c|c|}
\hline \multirow{2}{*}{$\begin{array}{c}\text { Villages } \\
\text { Abbreviation }\end{array}$} & \multicolumn{2}{|c|}{ RHV Rate (\%) } & \multicolumn{3}{|c|}{ Location } & \multicolumn{4}{|c|}{ Government Interventions } & \multicolumn{3}{|c|}{ Village's Characteristics } \\
\hline & Permanent & Temporary & SCL & TTMC & TTSC & CMP & VLP & HCR & FI & ID & FSR & PLA \\
\hline $\mathrm{CF}$ & 6.0 & 2.4 & 1 & 61 & 66 & 1 & 2 & 1 & 300 & 3 & 1 & 1 \\
\hline LJQ & 3.6 & 0.0 & 1 & 73 & 36 & 1 & 2 & 1 & 60 & 1 & 2 & 1 \\
\hline $\mathrm{ZC}$ & 10.5 & 3.0 & 1 & 67 & 32 & 2 & 1 & 2 & 7000 & 2 & 1 & 1 \\
\hline$X Y$ & 0.0 & 0.0 & 1 & 94 & 19 & 1 & 2 & 2 & 30 & 3 & 2 & 1 \\
\hline $\mathrm{HF}$ & 7.7 & 0.0 & 2 & 110 & 51 & 2 & 2 & 2 & 50 & 3 & 2 & 2 \\
\hline HST & 3.6 & 4.8 & 2 & 140 & 62 & 2 & 1 & 3 & 10,000 & 2 & 1 & 2 \\
\hline DJBZ & 8.5 & 1.7 & 2 & 100 & 80 & 2 & 1 & 2 & 55 & 3 & 5 & 4 \\
\hline DMK & 11.0 & 0.0 & 2 & 87 & 70 & 2 & 1 & 3 & 2000 & 3 & 1 & 1 \\
\hline SZ & 1.0 & 6.9 & 2 & 124 & 70 & 2 & 2 & 3 & 15 & 3 & 1 & 2 \\
\hline QYSW & 20.8 & 6.2 & 2 & 94 & 29 & 2 & 2 & 1 & 40 & 3 & 3 & 1 \\
\hline SX & 18.4 & 5.9 & 2 & 92 & 73 & 2 & 2 & 3 & 500 & 3 & 2 & 2 \\
\hline QTX & 12.2 & 6.1 & 2 & 96 & 70 & 2 & 2 & 3 & 60 & 3 & 3 & 2 \\
\hline ZJ & 7.2 & 2.4 & 2 & 150 & 80 & 2 & 1 & 3 & 50 & 3 & 3 & 1 \\
\hline GJB & 13.2 & 1.9 & 2 & 115 & 110 & 2 & 2 & 2 & 50 & 3 & 2 & 3 \\
\hline GJG & 12.5 & 12.5 & 2 & 144 & 70 & 2 & 2 & 3 & 40 & 3 & 3 & 2 \\
\hline MA & 6.2 & 4.8 & 3 & 142 & 52 & 1 & 2 & 1 & 150 & 3 & 1 & 1 \\
\hline SQW & 3.6 & 10.7 & 3 & 240 & 120 & 2 & 1 & 3 & 15,000 & 2 & 1 & 1 \\
\hline$\hat{\mathrm{M} Y}$ & 3.2 & 9.7 & 3 & 186 & 120 & 2 & 1 & 3 & 1200 & 2 & 1 & 2 \\
\hline LGW & 2.0 & 26.0 & 3 & 180 & 120 & 2 & 1 & 3 & 190 & 3 & 1 & 1 \\
\hline XFY & 5.1 & 5.1 & 3 & 150 & 92 & 2 & 2 & 3 & 60 & 3 & 2 & 2 \\
\hline $\mathrm{MC}$ & 4.9 & 6.6 & 3 & 145 & 110 & 2 & 2 & 3 & 15 & 3 & 3 & 2 \\
\hline ZSJ & 19.5 & 9.2 & 3 & 188 & 87 & 2 & 1 & 3 & 30 & 3 & 3 & 4 \\
\hline ZDT & 7.4 & 15.6 & 3 & 158 & 62 & 2 & 1 & 3 & 25 & 3 & 3 & 3 \\
\hline
\end{tabular}

Source: Authors' survey data.

For the three variables representing the location factor, we first look at the differences in geographical locations among villages. Specifically, there are 4 sampled villages located in the metropolitan fringe of Nanjing, 11 located in its inner suburbs, and 8 located in its outer suburbs. For the travel time by public transportation from the sampled villages to the main city center of Nanjing, there are 4 villages which are a 60-90 min drive away from the city center, 7 villages whose travel time to the city center is $90-120 \mathrm{~min}$, and 12 villages that are located more than a $120 \mathrm{~min}$ drive away from the city center. For the travel time from the sampled villages to the secondary city center of Nanjing, it takes less than $60 \mathrm{~min}$ for 6 villages to travel to the secondary city center, 60-90 min for 11 villages, and more than 90 min for 16 villages.

We then turn to the factor of government interventions. Specifically, there are four sampled villages located within the urban development boundary defined by the Master Plan of Nanjing, and 19 villages located outside the urban development boundary. According to the Village Layout Plan of Nanjing, our sampled villages include 10 reserved villages and 13 unreserved villages. In terms of the rural housing construction restrictions, 4 sampled 
villages are prohibited from new approval or renovation, 5 villages are prohibited from new approval but are allowed for housing renovation, and 14 villages are allowed for both new approval and renovation of rural houses. As for the amount of governments' financial investment received by villages in the past few years, there exists a huge gap among our sampled villages. Specifically, 5 villages received more than 10 million yuan, 4 villages received from 1 to 5 million yuan, and 14 villages received less than 600,000 yuan.

Finally, we look at the differences in the villages' characteristics. Specifically, there are 10 sampled villages that have better development of manufacturing or tourism, and 13 villages that are dominated by the agriculture economy. Among all the sampled villages, nearly $50 \%$ of these villages' farmland has been completely transferred. Besides, nearly $75 \%$ of the sampled villages have a farmland sublet rate of more than $80 \%$. There are also 19 sampled villages that have an agricultural employment rate of less than $30 \%$.

\section{Results and Discussions}

\subsection{The Impact of Location}

The relationship between the spatial circle of metropolitan where a village is located and its RHV rates are shown in Figure 5. It is clear to see that the permanent RHV rate of sampled villages in the suburbs of Nanjing does not increase as the locations of villages move from the metropolitan fringe to the outer suburbs, which is not in line with our theoretical expectation. While the permanent RHV rate of villages in Nanjing's metropolitan fringe is generally lowest, those located in the middle circle (i.e., the inner suburbs) have the highest average permanent RHV rate, and those in the outer suburbs are generally in the middle (Figure 5a). In contrast, the change of the temporary RHV rate of sampled villages located in different parts of Nanjing is as expected, which increases as the locations of villages move from the metropolitan fringe to inner suburbs and to outer suburbs (Figure $5 b$ ).

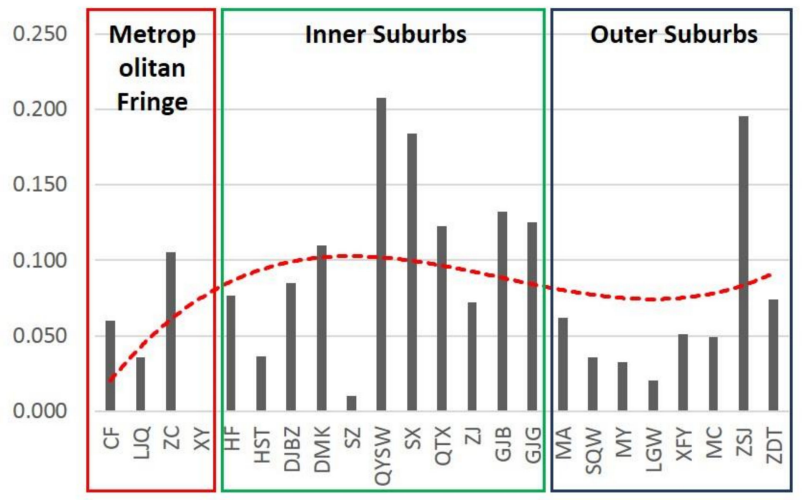

(a)

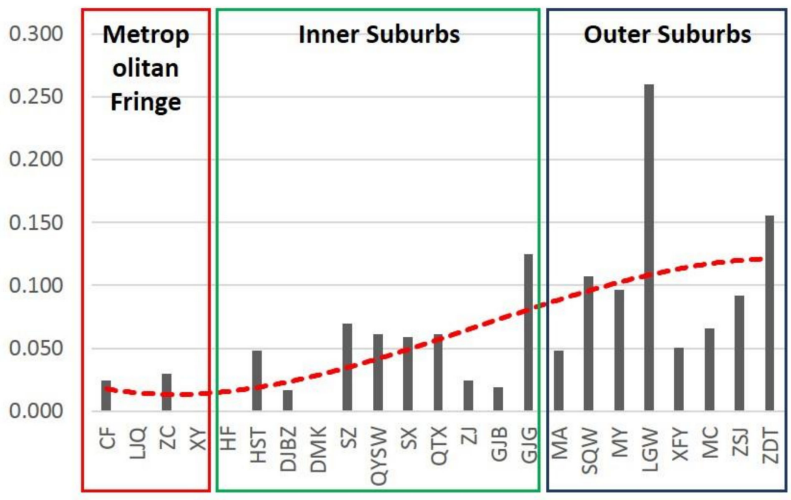

(b)

Figure 5. Relationship between spatial circle where villages are located and their RHV rates: (a) permanent RHV rate of sampled villages; (b) temporary RHV rate of sampled villages. (Source: These figures depicted by the authors based on survey data).

Figure 6a shows the relationship between the travel time by public transportation from a village to the main city center and its RHV rate. Similar to the above-discussed empirical results, the permanent RHV rate does not increase as the travel time increases while the temporary RHV rate is generally in line with our theoretical expectation. In fact, villages that are about a 90-120 min drive away from the main city center have a relatively higher permanent RHV rate than those that are located less than a 90 min drive away from the main city center. Figure $6 \mathrm{~b}$ shows the relationship between the travel time by public transportation from a village to the secondary city center and its RHV rate. Obviously, we can observe very similar results as shown in Figure 6a. 


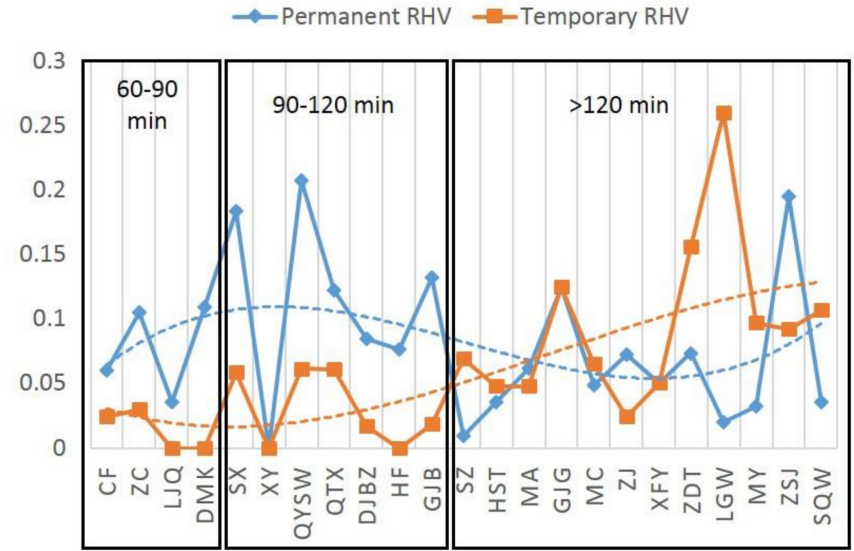

(a)

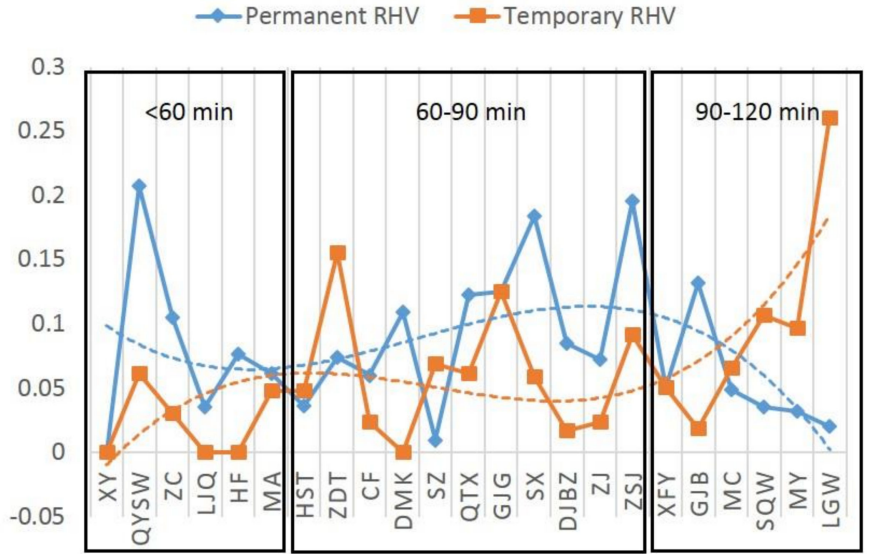

(b)

Figure 6. Relationship between travel time from villages to city centers and their RHV rates: (a) travel time from sampled villages to the main city center and RHV rates; (b) travel time from sampled villages to the secondary city center and RHV rates. (Source: These figures depicted by the authors based on survey data).

Clearly, both Figures 5a and 6 suggest that there is an unusual "middle bump" of permanent RHV rate in metropolitan suburbs. In this study, we find that the average permanent RHV rate is highest for villages that are located in the inner suburbs of Nanjing and have a medium travel time to city centers. The authors' findings are different from the law of RHV rate changing proposed by Song and Li. They advocate that the closer the villages are to city centers, the lower the RHV rate of the villages will be because they are close to workplaces and it is easy for migrant workers to move in [30,32]. Our findings are also different from the studies of Qiu and Tao. They argue that villages close to city centers have a higher RHV rate and the underlying mechanism is that in villages close to the city it is easier for residents to move to the city, so they are more likely to abandon their rural houses [33,34].

Based on the interviews with village managers and rural residents, we try to explain this unusual phenomenon from the perspective of residents' daily commuting circle and emergency commuting circle. In general, the main places of employment of villagers in metropolitan areas are the main city center as well as secondary city centers. Rural residents will rationally arrange their families' activities of employment, residence, and commuting between the city centers and the villages where their houses are located. For villages located in the metropolitan fringe, the commuting distance of rural people from their urban workplace to the villages is within the limit of the daily commuting circle (Figure 7a). Rural houses can be fully used every day by the families or be rented to migrants who work in the city centers, therefore the permanent RHV rate and temporary RHV rate of villages in this area are both lower.

However, for villages located in the inner suburbs, the distance to villagers' workplaces in city centers usually exceeds the limit of the daily commuting circle. Consequently, few people want to move to these villages, and the villagers tend to leave their rural houses and rent or buy houses close to their workplace. However, the commuting distance from people's workplace to the village is within the limit of the emergency commuting circle (Figure $7 \mathrm{~b}$ ). This means that when an emergency occurs in their original village, the residents can go back to their rural houses and return to their urban houses easily on the same day. Therefore, there is no need to maintain the living function of their rural houses and the permanent RHV rate of those villages is relatively higher. 


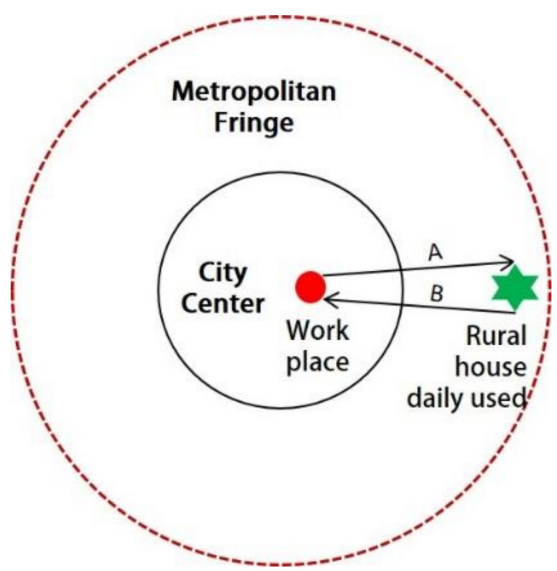

(a)

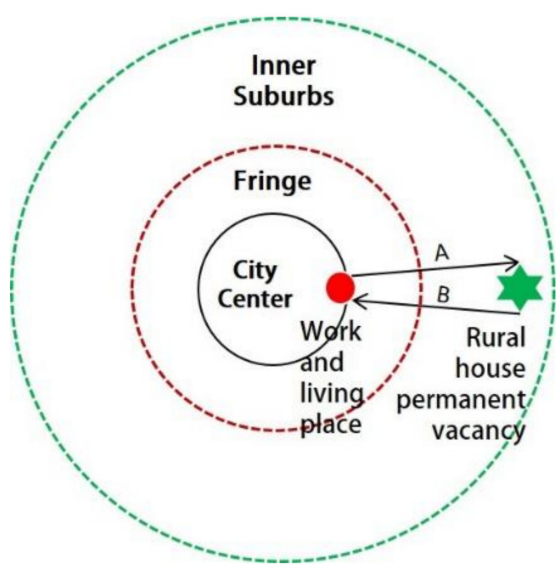

(b)

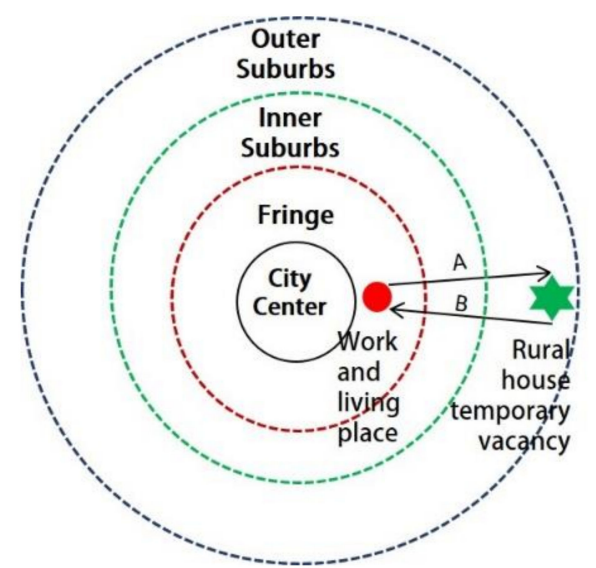

(c)

Figure 7. Schematic diagram of residents' commuting circle in different spatial locations: (a) Village in Metropolitan Fringe, A + B < Daily commuting circle; (b) Village in Inner Suburbs, Daily commuting circle $<$ A + B < Emergency circle; (c) Village in Outer Suburbs, A + B > Emergency circle. (Source: These figures depicted by the authors based on survey information).

However, for villages located in outer suburbs, the distance from the villagers' workplaces to city centers is not only longer than the daily commuting circle but also exceeds the emergency commuting circle. This means that if rural residents go back to their rural houses because an emergency happens in their villages, it would be difficult for them to return to their workplace within the same day (Figure 7c). Therefore, rural residents tend to maintain the living function of their rural houses, which could account for the lower average permanent RHV rate of those villages and higher average temporary RHV rate.

\subsection{The Impact of Government Interventions}

Table 3 shows the relationship between government interventions and the RHV rate. First, it suggests that the urban development boundary delineated by the City Master Plan has a significant impact on the RHV rate. However, in contrast with the theoretical expectations, the average permanent RHV rate and temporary RHV rate of villages within the urban development boundary are both lower than those located outside the urban development boundary. The sampled villages within the urban development boundary have an average permanent RHV rate of $4 \%$ and an average temporary RHV rate of $2 \%$, while the average permanent RHV rate and average temporary RHV rate of sampled villages outside the urban development boundary is $9 \%$ and $7 \%$, respectively.

Table 3. Relationship between government interventions and the RHV rate.

\begin{tabular}{|c|c|c|c|}
\hline Variables & Variables Connotation & $\begin{array}{l}\text { Average Permanent } \\
\text { RHV Rate }(\%)\end{array}$ & $\begin{array}{c}\text { Average Temporary } \\
\text { RHV Rate (\%) }\end{array}$ \\
\hline \multirow{2}{*}{ City master plan } & Village is within the urban development boundary & 4 & 2 \\
\hline & Village is outside the urban development boundary & 9 & 7 \\
\hline \multirow{2}{*}{ Village layout plan } & Plan reserved village & 6 & 8 \\
\hline & Plan unreserved village & 9 & 4 \\
\hline \multirow{3}{*}{$\begin{array}{l}\text { Housing construction } \\
\text { restriction }\end{array}$} & No new approval or renovation & 6 & 3 \\
\hline & No new approval but renovation allowed & 8 & 1 \\
\hline & Allow new approval and renovation & 8.5 & 9 \\
\hline \multirow{3}{*}{ Financial investment } & $>10,000,000.00$ yuan & 6 & 5 \\
\hline & $1,000,000.00-10,000,000.00$ yuan & 8 & 4 \\
\hline & $<1,000,000.00$ yuan & 9.4 & 5 \\
\hline
\end{tabular}


Second, it shows that whether villages are defined as reserved or unreserved villages could influence their RHV rates. Among the sampled villages, the average permanent RHV rate of reserved villages $(6 \%)$ is significantly lower than that of unreserved villages $(9 \%)$ defined according to the Village Layout Plan of Nanjing, which is consistent with our theoretical expectations. However, the average temporary RHV rate of reserved villages $(8 \%)$ is much higher than that of unreserved villages $(4 \%)$.

Third, it seems that the government's housing construction restrictions do not matter for the RHV rates of villages. Both the permanent RHV rate and temporary RHV rate are higher in villages with looser government housing construction restrictions, which is to some extent not in line with our theoretical hypotheses. Specifically, the sampled villages that allow new housing building and housing renovation have an average permanent RHV rate of $8.5 \%$ and average temporary RHV rate of $9 \%$ respectively, both of which are the highest.

Consistent with our theoretical expectations, the sampled villages that get more financial investments have lower average permanent RHV rates. Villages that received financial investment of less than 1 million in the past few years have an average permanent RHV rate of 9.4\%, while villages that received financial investment from 1-10 million have an average permanent RHV rate of $8 \%$, and those that received financial investment of more than 10 million have an average permanent RHV rate of $6 \%$. The more funding the villages received from the government, the lower their permanent RHV rates. However, the impact of financial investments on the temporary RHV rate is unclear.

The above analysis shows that reserved villages defined by the Village Layout Plan of Nanjing and villages that obtained large financial investment have relatively lower permanent RHV rates and relatively higher temporary RHV rates. In other words, the supportive plans and financial investment increase the use of rural housings in these villages. Through interviews with rural residents, we found that the supportive plans have promoted the development of new industries in the villages and created new job opportunities, which have led to fundamental transformations of these villages. Take the ShiQiangWei (SQW) Village as an example. After receiving hundreds of millions in financial construction investments, the environment of this hillside village has been greatly improved. As the village gradually transformed into a tourism village, many villagers are engaged in tourism service industries such as catering and holiday inn. Moreover, new industries such as Internet innovation, creative industries, and commercial offices are also developing in this village, and previously vacant rural houses are being reused. Due to the development of new industries and the creation of new employment opportunities in SQW, the two types of RHV rates have declined. This is consistent with many existing studies conclusions, that is, those well-planned villages are also key government-invested villages, where public facilities are complete, new job opportunities are created, and rural houses are fully used [34,44-46].

Moreover, we found that some sampled villages have not developed new industries, but some of their previously abandoned houses have also been reused when state financial investment improved the amenity of the village. From the experience of developed countries, rural amenity attracts high-income urban residents, retirees, and innovative and creative talents into the countryside [54,55]. The phenomenon of counter-urbanization or suburbanization in some European cities is part of the result of urban residents' pursuit for rural amenity [56]. However, because of the barrier of the urban-rural dual land system in China, rural land is collectively owned, and urban residents are prohibited from buying houses in the countryside, so China's suburbanization is very slow [36]. However, during the interviews with residents of sampled villages such as ShanXi (SX) and ShenZhuang (SZ), the authors found that some residents with higher income levels who left the village many years ago are returning to their original village and renovating their old houses. Some of the returned original villagers are retirees, while others have turned their rural houses into their second homes. In these villages, due to the restoration of residential 
functions, the permanent RHV rate reduced while the temporary RHV rate increased. However, this latest phenomenon has rarely been noticed in China's hollow village studies.

Our empirical results also show that the urban development boundary delineated by the City Master Plan and stronger housing construction restrictions have not increased the RHV rates. Although the government's restrictive measures caused the deterioration of the rural living environment, they are not the main reason for residents leaving the villages. Through the interviews with villagers, we found that the villages located within the urban development boundary and villages with stronger restrictions are also the villages close to the city's employment center. Therefore, these villages have a large number of inflow immigrants, which is conducive to make full use of all the rural houses. For instance, the number of immigrant workers in LuJiaQiao (LJQ) Village is about two times that of residents with local household registrations, while the number of immigrant workers in CaoFang (CF) Village is equal to the local population. The main objective of immigrant workers living in these villages is for employment and higher income. Generally, they do not have high requirements for the living environment but are very sensitive to the rent price. This is consistent with the findings of existing studies on urban villages and urban border villages in China's metropolitan areas $[57,58]$.

\subsection{The Impact of the Villages' Characteristics}

Table 4 shows the relationship between the villages' characteristics and their RHV rates. It is obvious to see that the permanent RHV rate is significantly lower in the villages that have better development of manufacturing and rural tourism industries than that in the villages that are dominated by an agricultural economy. The average permanent RHV rate of non-agricultural villages is $4 \%$, while the average permanent RHV rate of agricultural villages is $9 \%$. However, the impact of the development of rural industries on the temporary RHV rate is not obvious, as the average temporary RHV rate of the two types of villages is nearly the same.

Table 4. Relationship between the villages' characteristics and the RHV rate.

\begin{tabular}{|c|c|c|c|}
\hline Variables & Variables Connotation & $\begin{array}{c}\text { Average Permanent RHV } \\
\text { Rate }(\%)\end{array}$ & $\begin{array}{c}\text { Average Temporary RHV } \\
\text { Rate }(\%)\end{array}$ \\
\hline \multirow{2}{*}{ Industry development } & Village has non-agricultural development & 4 & 6 \\
\hline & Agricultural village & 9.8 & 6 \\
\hline \multirow{3}{*}{ Farmland sublet rate } & $<80 \%$ & 12 & 7.5 \\
\hline & $80-100 \%$ & 8 & 2 \\
\hline & $100 \%$ & 5 & 7.5 \\
\hline \multirow{4}{*}{$\begin{array}{l}\text { Proportion of local labor } \\
\text { engaged in agriculture }\end{array}$} & $<10 \%$ & 7 & 5.5 \\
\hline & $10-30 \%$ & 8 & 6 \\
\hline & $30-50 \%$ & 10 & 8 \\
\hline & $>50 \%$ & 14 & 5 \\
\hline
\end{tabular}

Source: Authors' survey data.

It is also found that villages with a higher rate of farmland subletting have a lower permanent RHV rate. Specifically, villages with an agricultural land sublet rate of less than $80 \%$ have a much higher average permanent RHV rate than those that sublet all their farmland. However, the relationship between the village's sublet rate of farmland and the temporary RHV rate is unclear.

Sampled villages with a higher proportion of local labor engaged in agriculture have a significantly higher permanent RHV rate, which is in contrast with theoretical expectations. The average permanent RHV rate is over $10 \%$ in villages where more than $30 \%$ of their local labor is engaged in agriculture, while the average permanent RHV rate is less than $8 \%$ in villages where less than $30 \%$ of their local workers are engaged in agriculture. However, 
the relationship between the temporary RHV rate and the ratio of local workers engaged in agriculture is unclear.

The above analysis shows that the permanent RHV rate is significantly lower in villages with better development of non-agricultural industries. This result is also in line with Qiu and Yang's research conclusions [33,51]. In fact, we found that industries such as the labor-intensive textile industry, small machining industry, and tourism service industry in the metropolitan suburbs are especially capable of absorbing middle-aged and female workers aged 30-60. Residents in these sampled villages can work and live nearby, and their houses can be used continuously.

The result shows that the permanent RHV rate is relatively lower in villages with a higher farmland sublet rate and a lower proportion of local laborers engaged in agriculture. This is exactly the opposite of our theoretical hypothesis, and it is also different from the conclusions of many other scholars' studies. According to the research of $\mathrm{Xu}$ and Yang, if rural residents no longer engage in agriculture, the possibility of them moving into the city will increase, which leads to the occurrence of RHV [35,51].

Combined with the interviews with the villagers, we try to use the concept of the filling effect of the agricultural population to explain this abnormal phenomenon. Through the field survey and interviews with the villagers, we recognized that villages that have a higher rate of farmland subletting and a lower ratio of local agriculture workers usually have a considerable immigrant farming population. In the sampled villages, for example, CF Village, SZ Village, and XuanYe (XY) Village have no tourism service industries, but each village has dozens of immigrant farming families from the relatively undeveloped northern area of Jiangsu Province and neighboring Anhui Province. Immigrant farmers rent farmland and rural houses from the local villagers, each immigrant family farming generally has two or three laborers and cultivates 10-30 mu of farmland (0.7-2 hectares), and are mainly engaged in labor-intensive urban agriculture such as the planting of vegetables, flowers, and fruits. Since these types of agriculture need to be close to the urban consumer market, villages with a higher farmland subletting rate and a lower ratio of local agriculture workers are actually those with excellent traffic accessibility. The role of this special group in the utilization of vacant rural houses has not attracted enough attention in China.

\subsection{Policy Implications}

Based on the above analysis of factors affecting the RHV rates in Nanjing's metropolitan suburbs, we further put forward some policy suggestions in terms of reducing the RHV rate and realizing the sustainable development of urban-rural space at the regional scale.

First, the local governments should continue to increase the financial investment of rural public facilities in metropolitan suburbs. This study has shown that financial investments could promote the development of rural industries and improve rural amenities, which could further increase employment opportunities in rural areas and attract urban populations to live in the villages. In this sense, the original vacant housings in these villages are more likely to be reused.

Second, the local governments should appropriately loosen their restrictions over rural construction activities within the urban development boundary. Because there are numerous immigrant workers in these villages, the government's construction restrictions have deteriorated their living environment, which is a manifestation of social injustice. Therefore, we suggest that rural areas within the boundary of urban development should be allowed to carry out some livability improvement development.

Third, it is necessary to make different strategies for the development of different types of villages. For villages that have industrial development, more support should be given to creating new employment opportunities if the industries have no negative effect on the rural environment. For villages that have tourism development, excessive commercial development should be avoided in order to protect local features. 
Fourth, the local government should provide necessary public service facilities for immigrant farming families. The immigrant farming population occupies the rural areas of metropolitan suburbs, provides vegetables and fruits to the city, and utilizes the farmland and vacant rural houses. They are playing an important role in the sustainable development of rural areas in metropolitan suburbs but are often neglected in the policymaking system. For example, the local government can facilitate the schooling of their children and improve the livability of the villages where they are currently staying.

\section{Conclusions}

During the process of rapid industrialization and urbanization, China's rural areas have experienced widespread population loss and spatial decline. Even in some developed metropolitan areas, many villages in the suburbs are also facing the problem of rural housing vacancy (RHV). Taking the example of Nanjing in China and drawing upon detailed survey data on 23 sampled villages, this paper finds that permanent vacant rural houses and temporary vacant rural houses are common in villages of metropolitan suburbs. The two types of RHV rates are affected by three categories of factors including location, government interventions, and the villages' characteristics.

Specifically, our empirical results show that villages located in inner suburbs and with medium travel time to city centers have higher permanent RHV rates, while those located further from city centers usually have higher temporary RHV rates. Local governments' restrictive plans and housing construction restrictions do not increase permanent RHV rates nor temporary RHV rates, whereas supportive plans and financial investment reduce permanent RHV rates and increase temporary RHV rates. Permanent RHV rates are relatively lower in villages that are less reliant on agriculture development. Those villages usually have higher sublet rates of farmland, a lower proportion of local agriculture laborers, and better development of manufacturing or tourism. However, temporary RHV rates do not differ significantly between agriculture villages and non-agriculture villages.

To sum up, the differentiation of RHV rates in the suburbs of metropolitan areas is the result of the combined effects of three categories of factors. Under the law of commuting circles, some villages have developed non-agricultural industries, attracted immigrant manufacturing workers and immigrant farmers, and restored residential functions because of the improving rural amenities. These have triggered fundamental rural transformations in these villages, which have accounted for the decreasing permanent RHV rate and the increasing temporary RHV rate. However, some villages have experienced a higher rate of permanent RHV, due to the stagnated industrial development, a low inflow of immigrants, and a less attractive living environment.

In this paper, the authors make conceptual and empirical contributions to the understanding of the RHV issue in China's suburbs of metropolitan areas. We contribute to the literature in the following aspects: (1) this paper distinguishes RHV into permanent RHV and temporary RHV, which is more in line with the reality of the phenomenon of RHV but ignored by most existing studies. In particular, we found that the temporary RHV is even conducive to solving the problem of rural recession. (2) The study finds that there is an unusual "middle bump" of the permanent RHV rate, that is, a village in the inner suburbs and with medium travel time to city centers has a higher permanent RHV rate. In this regard, we used the concepts of "daily commuting circle" and "emergency commuting circle" to interpret it. (3) This study also discussed the restoration of the residential functions of rural houses caused a desire for rural amenity while existing studies pay more attention to rural houses reused brought about by the development of tourism. (4) Similar to many studies, this study also found that there are many immigrant workers who are moving to China's rural area of metropolitan suburbs. Not only that, we discovered the filling effect of immigrant farmers on the rural area has increased the utilization rate of rural houses.

This paper has some shortcomings which could serve as departure points for future studies. For instance, due to a relatively limited number of sampled villages, we are unable to empirically analyze the exact impact of different factors on the RHV rate. Future 
studies could conduct more field surveys and adopt econometric approaches to examining their relationships. In addition, since the outbreak of COVID-19, China's government has attached great importance to urban-rural balance and the overall security of metropolitan areas. The residential value of rural houses has increased significantly in the rural area of metropolitan suburbs, and the willingness of urban residents to go to or return to the countryside has also increased. How this will affect RHV needs to be further tracked and studied.

Author Contributions: Conceptualization, L.Z. and X.W.; methodology, L.Z.; formal analysis, X.W. and L.Z.; investigation, L.Z. and X.W.; writing—original draft preparation, L.Z.; writing-review and editing, X.W. and L.Z.; supervision, X.W. All authors have read and agreed to the published version of the manuscript.

Funding: This research received no external funding.

Institutional Review Board Statement: Not applicable.

Informed Consent Statement: Not applicable.

Data Availability Statement: Not applicable.

Acknowledgments: The authors want to thank the town government officials and village managers who assisted our field investigations in sampled villages. The authors also want to thank the village managers and villagers who accepted our interviews for their very sincere and enlightening feedback. In addition, the authors want to thank Yingcheng Li for his proofreading of this paper.

Conflicts of Interest: The authors declare no conflict of interest.

\section{References}

1. Krannich, R.; Luloff, A.E.; Field, D.R. People, Places and Landscapes: Social Change in High Amenity Rural Areas; Springer: London, UK; New York, NY, USA, 2011; p. 125.

2. McGreevy, S.R. Lost in translation: Incomer organic farmers, local knowledge, and the revitalization of upland Japanese hamlets. Agric. Hum. Values 2012, 29, 393-412. [CrossRef]

3. Collantes, F.; Pinilla, V.; Sáez, L.A.; Silvestre, J. Reducing Depopulation in Rural Spain: The Impact of Immigration. Popul. Space Place 2014, 20, 606-621. [CrossRef]

4. Reynaud, C.; Miccoli, S.; Benassi, F.; Naccarato, A.; Salvati, L. Unravelling a demographic 'Mosaic': Spatial patterns and contextual factors of depopulation in Italian Municipalities, 1981-2011. Ecol. Indic. 2020, 115, 106356. [CrossRef]

5. Gans, P. Urban Population Development in Germany (2000-2014): The Contribution of Migration by Age and Citizenship to Reurbanisation. Comp. Popul. Stud. 2017, 42, 42.

6. ESPON. Shrinking Rural Regions in Europe. Towards Smart and Innovative Approaches to Regional Development Challenges in Depopulating Rural Regions. 2017. Available online: https://www.espon.eu/sites/default/files/attachments/ESPON\%20 Policy\%20Brief\%20on\%20Shrinking\%20Rural\%20Regions.pdf (accessed on 16 October 2020).

7. Wei, H.; Yan, K. China Rural Development Report: Inspiring New Momentum for Rural Development by Comprehensively Deepening Reforms; China Social Sciences Press: Beijing, China, 2017; p. 23. (In Chinese)

8. Liu, Y.; Long, H.; Chen, Y.; Wang, J. China Rural Development Research Report: Rural Hollowing and Its Remediation Strategy; Science Press: Beijing, China, 2011. (In Chinese)

9. Zhang, Y.; Li, X.; Song, W.; Zhai, L. Land abandonment under rural restructuring in China explained from a cost-benefit perspective. J. Rural. Stud. 2016, 47, 524-532. [CrossRef]

10. Wang, Y.; Peng, P.; Li, Q.; Chen, Z.; Tang, W. Spatial Heterogeneity of Farmland Abandonment in the Sichuan Province, China. Sustainability 2020, 12, 3356. [CrossRef]

11. Liu, Y.; Li, Y. Revitalize the world's countryside. Nature 2017, 548, 275-277. [CrossRef]

12. Zang, Y.; Liu, Y.; Yang, Y.; Woods, M.; Fois, F. Rural decline or restructuring? Implications for sustainability transitions in rural China. Land Use Policy 2020, 94, 104531. [CrossRef]

13. Sun, H.; Liu, Y.; Xu, K. Hollow villages and rural restructuring in major rural regions of China: A case study of Yucheng City, Shandong Province. Chin. Geogr. Sci. 2011, 21, 354-363. [CrossRef]

14. Long, H.; Li, T. The coupling characteristics and mechanism of farmland and rural housing land transition in China. J. Geogr. Sci. 2012, 22, 548-562. [CrossRef]

15. Song, W.; Liu, M. Assessment of decoupling between rural settlement area and rural population in China. Land Use Policy 2014, 39, 331-341. [CrossRef]

16. Li, J.; Guo, M.; Lo, K. Estimating Housing Vacancy Rates in Rural China Using Power Consumption Data. Sustainability 2019, 11, 5722. [CrossRef] 
17. Xu, F.; Ho, H.C.; Chi, G.; Wang, Z. Abandoned rural residential land: Using machine learning techniques to identify rural residential land vulnerable to be abandoned in mountainous areas. Habitat Int. 2019, 84, 43-56. [CrossRef]

18. Long, H.; Liu, Y.; Li, X.; Chen, Y. Building new countryside in China: A geographical perspective. Land Use Policy 2010, 27, 457-470. [CrossRef]

19. Long, H.; Li, Y.; Liu, Y.; Woods, M.; Zou, J. Accelerated restructuring in rural China fueled by 'increasing vs. decreasing balance' land-use policy for dealing with hollowed villages. Land Use Policy 2012, 29, 11-22. [CrossRef]

20. Li, Y.; Wu, W.; Liu, Y. Land consolidation for rural sustainability in China: Practical reflections and policy implications. Land Use Policy 2018, 74, 137-141. [CrossRef]

21. Tian, Y.; Kong, X.; Liu, Y.; Wang, H. Restructuring rural settlements based on an analysis of inter-village social connections: A case in Hubei Province, Central China. Habitat Int. 2016, 57, 121-131. [CrossRef]

22. Sun, X.; Zhang, Z.; Zhang, Y. Factors Influencing Farmer's Decision-Making Behavior on Rural Construction Land Transformation. Sustainability 2018, 10, 4288. [CrossRef]

23. Li, Y.; Westlund, H.; Zheng, X.; Liu, Y. Bottom-up initiatives and revival in the face of rural decline: Case studies from China and Sweden. J. Rural Stud. 2016, 47, 506-513. [CrossRef]

24. Gao, X.; Xu, A.; Liu, L.; Deng, O.; Zeng, M.; Ling, J.; Wei, Y. Understanding rural housing abandonment in China's rapid urbanization. Habitat Int. 2017, 67, 13-21. [CrossRef]

25. $\mathrm{Wu}, \mathrm{Y}$; Z Zhou, Y.; Liu, Y. Exploring the outflow of population from poor areas and its main influencing factors. Habitat Int. 2020 99, 102161. [CrossRef]

26. Lu, Q.; Cui, H.; Liu, J. Impact of COVID-19 on Rural Residents' Income and Suggestions on Promoting the Sustainable Income Increase for Rural Residents. Issues in Agricultural Economy 2020, 8, 12-23. (In Chinese)

27. Chen, S.; Su, S. Farmers' Livelihood Risks and Countermeasures under the Impact of Major Epidemic: Case Study based on the Mountainous Areas of Fujian. J. Fujian Agric. For. Univ. (Philos. Soc. Sci.) 2020, 23, 1-6. (In Chinese)

28. Gao, F. New Propositions and New Transformation in the Evolution of Urban-rural Relation in China after the Epidemic. Explor. Free Views 2020, 10, 111-121. (In Chinese)

29. Liu, Z.; Wang, Z. Impact of COVID-19 on Wuhan Residents' Willingness of Rural Homestead Land Transfer. Hubei Agric. Sci. 2020, 59, 195-198. (In Chinese)

30. Song, W.; Chen, B.; Zhang, Y. Typical Survey and Analysis on Influencing Factors of Village-hollowing of Rural Housing Land in China. Geogr. Res. 2013, 32, 20-28. (In Chinese)

31. Li, C.; Wu, K. Driving forces of the villages hollowing based on geographically weighted regression model: A case study of Longde County, the Ningxia Hui Autonomous Region, China. Nat. Hazards 2017, 89, 1059-1079. [CrossRef]

32. Li, T.; Long, H.; Wang, Y. Analysis of Idleness of Rural Residential Land and Its Causes in China. China Land Sci. 2019, 33, 64-71. (In Chinese)

33. Qiu, J.; Niu, P.; Chen, W.; Chen, Y.; Yin, Q. The Status Quo, Characteristics and Influencing Factors of Hollow Village in the Suburbs of the City. Jiangsu Agric. Sci. 2019, 47, 313-317. (In Chinese)

34. Tao, Z.; Guanghui, J.; Guangyong, L.; Dingyang, Z.; Yanbo, Q. Neglected idle rural residential land (IRRL) in metropolitan suburbs: Spatial differentiation and influencing factors. J. Rural Stud. 2020, 78, 163-175. [CrossRef]

35. Xu, D.; Zhang, J.; Xie, F.; Liu, S.; Cao, M.; Liu, E. Influential factors in employment location selection based on "push-pull" migration theory-a case study in Three Gorges Reservoir area in China. J. Mt. Sci. Engl. 2015, 12, 1562-1581. [CrossRef]

36. Liu, Y.; Liu, Y.; Chen, Y.; Long, H. The process and driving forces of rural hollowing in China under rapid urbanization. J. Geogr. Sci. 2010, 20, 876-888. [CrossRef]

37. Lang, W.; Chen, T.; Li, X. A new style of urbanization in China: Transformation of urban rural communities. Habitat Int. 2016, 55, 1-9. [CrossRef]

38. Ma, W.; Jiang, G.; Wang, D.; Li, W.; Guo, H.; Zheng, Q. Rural settlements transition (RST) in a suburban area of metropolis: Internal structure perspectives. Sci. Total Environ. 2018, 615, 672-680. [CrossRef]

39. Wei, C.; Shi, M. Governance and Homestead System Reform of "Hollow Villages": Based on the Investigation of Fuxian County in Guangxi Province. City Plan. Rev. 2017, 41, 63-69. (In Chinese)

40. Capello, R. Location, Regional Growth and Local Development Theories. Géographie Économie Société 2009, 11, 1. [CrossRef]

41. Pölling, B.; Mergenthaler, M. The Location Matters: Determinants for "Deepening" and "Broadening" Diversification Strategies in Ruhr Metropolis' Urban Farming. Sustainability 2017, 9, 1168. [CrossRef]

42. Manoj, M.; Verma, A.; Navyatha, M. Commute travel and its effect on housing tenure choice of males and females living in the urban and rural areas of Bangalore city in India. J. Transp. Geogr. 2015, 45, 62-69. [CrossRef]

43. Li, H.; Wei, Y.D.; Wu, Y. Urban amenity, human capital and employment distribution in Shanghai. Habitat Int. 2019, 91, 102025. [CrossRef]

44. Lo, K.; Xue, L.; Wang, M. Spatial restructuring through poverty alleviation resettlement in rural China. J. Rural Stud. 2016, 47, 496-505. [CrossRef]

45. Liu, C.; Dou, X.; Li, J.; Cai, L.A. Analyzing government role in rural tourism development: An empirical investigation from China. J. Rural. Stud. 2020, 79, 177-188. [CrossRef]

46. Xi, J.; Zhao, M.; Ge, Q.; Kong, Q. Changes in land use of a village driven by over 25 years of tourism: The case of Gougezhuang village, China. Land Use Policy 2014, 40, 119-130. [CrossRef] 
47. Chen, C.; Woods, M.; Chen, J.; Liu, Y.; Gao, J. Globalization, state intervention, local action and rural locality reconstitution-A case study from rural China. Habitat Int. 2019, 93, 102052. [CrossRef]

48. Lee, E.S. A Theory of Migration. Demography 1966, 3, 47-57. [CrossRef]

49. Bogue, D.J. Principles of Demography; John Wiley \& Sons Inc.: New York, NY, USA, 1969.

50. Wu, J.; Yu, Z.; Wei, Y.D.; Yang, L. Changing distribution of migrant population and its influencing factors in urban China: Economic transition, public policy, and amenities. Habitat Int. 2019, 94, 102063. [CrossRef]

51. Yang, T. Research on the Influencing Factors and Reuse Methods of Idle Homesteads: Based on a Survey in Yangchun, Guangdong Province. Master's Thesis, Lanzhou University, Lanzhou, China, 2020. (In Chinese).

52. Chen, J.; Gao, J.; Chen, W. Urban land expansion and the transitional mechanisms in Nanjing, China. Habitat Int. 2016, 53, 274-283. [CrossRef]

53. Zhao, L.; Wang, X. Study on Temporal and Spatial Characteristics of Townships Merging and Merged Towns Development in the Process of Metropolitanization: A Case of Nanjing. Mod. Urban Res. 2019, 60-68. (In Chinese)

54. Perkins, H.C.; Mackay, M.; Espiner, S. Putting pinot alongside merino in Cromwell District, Central Otago, New Zealand: Rural amenity and the making of the global countryside. J. Rural Stud. 2015, 39, 85-98. [CrossRef]

55. Green, G.; Deller, S.; Marcouiller, D. Amenities and Rural Development: Theory, Methods, and Public Policy; Edward Elgar Publishing: Northampton, UK, 2005; pp. 1-5.

56. Cuadrado-Ciuraneta, S.; Durà-Guimerà, A.; Salvati, L. Not only tourism: Unravelling suburbanization, second-home expansion and "rural" sprawl in Catalonia, Spain. Urban Geogr. 2017, 38, 66-89. [CrossRef]

57. Zacharias, J.; Lei, Y. Villages at the urban fringe-The social dynamics of Xiaozhou. J. Rural Stud. 2016, 47, 650-656. [CrossRef]

58. Liu, Y.; Zhang, F.; Wu, F.; Liu, Y.; Li, Z. The subjective wellbeing of migrants in Guangzhou, China: The impacts of the social and physical environment. Cities 2017, 60, 333-342. [CrossRef] 